Смиљана Ж. ЂОРЂЕВИЋ БЕЛИЋ* Институт за књижевност и уметност Београд
Оригинални научни рад

Примљен: 19. 02. 2019.

Прихваћен: 07. 05. 2019.

\title{
ПРИЧЕ О СНОВИМА: ПРОБЛЕМИ, МОГУЋНОСТИ И ПЕРСПЕКТИВЕ ПРОУЧАВАҢА**
}

Премда представљају продуктиван и виталан фолклорни жанр, приче о сновима у обзорје фолклористичких интересовања ушле су релативно касно, тек крајем осамдесетих и почетком деведесетих година 20. века. Овај рад има за циљ да у најкраћем представи основна проблемска поља у фолклористичким истраживањима прича о сновима, те да укаже на могуће правце и перспективе будућих проучавања у оквирима науке о фолклору у Србији. живања

Кључне речи: сан, усмени сановник, приче о сновима, фолклор, теренска истра-

\section{Приче о сновима: ка концептуализацији фолклорног жанра}

Иако представљају продуктиван и виталан фолклорни жанр, приче о сновима у обзорје фолклористичких интересовања (у ужем смислу1) ушле су сразмерно касно, тек крајем осамдесетих и почетком деведесетих година 20. века. Занимање за снове у оквирима традицијске културе, за њихову семантику и симболику, те за уклапање у шири систем традицијских представа и културних концепата карактерише особито етнолингвистичке приступе, којима су теоријски темељи постављени у студијама Н. Толстоја (Толстой $1993)$ и С. Њебжеговске (Небжеговска 1994). Усмерена на анализу карактера везе између симбола из сна и његовог значења, ова истраживања почивају на претпоставци о „народном сановнику” као стабилном комплексу семан-

\footnotetext{
*smiljana78@yahoo.com

** Рад је настао у оквиру пројекта Српско усмено стваралаштво у интеркултурном коду, који финансира Министарство просвете, науке и технолошког развоја РС (178011).

${ }^{1}$ Проучавања снова имају дугу историју у оквирима културне антропологије, семиотике, студија културе; историјат и интерпретација истраживања понуђени су у Панченко 2002: 10-12; Рабинович 2013: 9-56.
} 
тичких веза које су сачуване и фиксиране у колективном знању. Кроз логику тумачења рефлектују се и фолклорне представе о природи сна и сневања. „Усмени сановник” је семантички стабилан, има јасну структуру $(\mathrm{X} \rightarrow \mathrm{Y})$ и прагматику (предвиђање будућности). Стога се као основни задатак издваја проучавање принципа интерпретације симбола, као и реконструкција слике света и система вредности носилаца одређене културе, будући да минимални текст тумачења сна увек имплицитно има и процењујући предзнак (Небжеговска 1994: 72). Толстој истиче да се „народни сановник” може испитивати на тематском и географском плану применом упоредно-историјског и ареалног метода, при чему је први усмерен на реконструкцију културе, а други на утврђивање културних дијалеката.

У истраживањима која се од разматрања минималних текстова тумачења сна окрећу нарацијама о сновима поставља се и питање теоријске концептуализације прича о сновима као фолклорног жанра, које се даље грана на више проблемских подручја. Једно од најважнијих је, свакако, дефинисање везе оваквих нарација са традицијом у најширем смислу. Проблем је отворен већ у једном од пионирских истраживања на овом пољу, које је спровела А. Кајвола-Брегенхој (Kaivola-Bregenhøj 1993). Осврћући се и на психолошке и психоаналитичке приступе, ауторка подсећа да за тумачење сна није довољно посматрати га на фону укупног искуства индивидуе, већ и кроз социјални и културни контекст који индивидуу окружује. Управо окретање овом контексту отвара могућност да снови буду предмет интересовања антрополога, фолклориста, социолога. Проблем ,традиционалности” прича о сновима на особито комплексан начин сагледан је у студијама Ј. Сафронова (в. посебно Сафронов 2006а), чије се хипотезе ослањају на Бахтинов концепт говорних жанрова, схватања фолклора изнесена у студијама Б. Путилова и К. Чистова, те на искуства семиотике (нарочито на идеје Ј. Лотмана). Сагледавајући приче о сновима у светлу фундаменталних карактеристика фолклора, овај истраживач констатује да су за разликовање „фолклорних” и „нефолклорних"2 снова посебно релевантни критеријуми усмерености на традицију, инклузивности, прагматике и варијантности, док анонимност и колективност (у смислу високог степена „обезличавања”) нису пресудни (слично меморату и наративима личног искуства уопште). Овај истраживач успоставља разлику између три семиотичка типа прича о сновима, од оних свакодневних, које се само једном саопштавају, преко прича које у ограниченом периоду функционишу у релативно малој групи (и у којима се не успостављају дубоке контекстуалне и културне везе са таквом малом заједницом), до прича о сновима које припадају сфери фолклора. Ипак, Сафронов наглашава да је немогуће успоставити сасвим јасне границе између различитих семиотичких типова. Аутор даље примећује да су сви говорни жанрови (како их је

\footnotetext{
${ }^{2}$ Премда се у низу студија о сновима проблем не дискутује посебно, избор истраживача посредно говори и о критеријумима који се виде као релевантни за препознавање наратива о сну као фолклорног. Реч је најчешће о садржају, значењу, варијантности, могућности успостављања типологије које одређени корпуси снова нуде, те се истраживачи окрећу пророчким сновима, сновима о умрлима, сновима везаним за култна места и сл.
} 
дефинисао М. Бахтин) ослоњени на одређену традицију, да се креирају у односу на постојеће моделе, али фолклорни текстови (укључујући и приче о сновима које се могу одредити као фолклорне) успостављају везе према посебном типу традиције - према „традицији идеја”, која се поима као систем надлингвистичких, метатекстуалних веза, које су изражене не само кроз жанровске законитости, већ и кроз репродукцију типичних мотива, слика, сижеа; продукција фолклорног текста подразумева познавање система претходних текстова, њихове типологије, семантике и функције. Додатно, за фолклорну трансмисију неопходна је фолклорна свест која је, како истиче Сафронов, такође традиционална. Укупности значења кодираних у култури и традицији онај ко сања не окреће се само у интерпретацији сна, већ ова значења утичу и на прво, сасвим неструктурисано, сећање на сан. Стога се већ на овом ступњу (ступњу „превођења” психолошко-физиолошког искуства у наратив) може говорити о зачецима фолклоризације ${ }^{3}$ (Сафронов 2006а; уп. Рабинович 2013: 47; Hesz 2012: 143). У процесу трансформисања искуства у наратив сневач следи утврђене наративне моделе - конвенције везивања секвенци у кохерентан текст (Kaivola-Bregenhøj 1993: 217).

Питања наративног обликовања и преношења искуства сневања односе се и на избор сна који ће бити интерпретиран, те се, између осталог, истиче и значај индивидуалне процене занимљивости/релевантности сна. Тако И. Разумова (2001: 86) констатује да ће се чешће фолклоризовати они снови које сами сневачи везују за сферу „сакралне информације”, тумачећи их у симболичком кључу ${ }^{4}$. Однос сневача према сну зависи, разуме се, и од тога да ли се догађај за који се сан везује одиграо или није: реч може бити о једноставном препричавању сна, или, ако се догађај одиграо, о сасвим новом тексту који има другачији статус и другачије контекстуалне и функционалне везе са сфером социјалног живота (Сафронов 2008а: 7-8); „обистињавање” (претходно препричаваног) сна доводи до ојачавања везе између знака/симбола и интерпретативног модела (Bregenhøj 1993) (у том правцу разликују се приче о сновиђењима и приче о сновима који су се „обистинили”; в. Веселова 2002: 172). Колективно искуство одређује и меру препознатљивости типа наратива, те је тако за приче о сновима очекивана епизодична структура, успостављање каузално-темпоралних веза, одређена мера занимљивости, али слушаоце неће изненадити ни нелогичност и фрагментарност (KaivolaBregenhøj 1993: 216-217; о одликама дискурса снова в. Shanon, Eiferman 1984). За формирање, рецепцију и потенцијалну трансмисију прича о сновима важни су, наглашава већина теоретичара, и унутартекстовни (структура, семантика - усмереност на значења валидна на личном и ширем социјалном нивоу, вредности кодиране културом и традицијом, нпр. присуство препознатљивих мотива, начин концептуализације простора и времена и сл.), као

\footnotetext{
${ }^{3}$ Слична промишљања у вези са статусом мемората изнесена су, да подсетимо, у студијама Х. Баузингера и Л. Хонка.

4 ,Профане“ снове ауторка одређује као оне чија се генеза објашњава свакодневним животним околностима, који не захтевају тумачење и не доводе се у везу са потоњим догађајима у социјалној сфери.
} 
и вантекстовни елементи (комуникативна ситуација, обредни/свакодневни контекст, социокултурна атмосфера и сл.). Даљим преношењем прича о сну може се додатно схематизовати према обрасцима који су за одређени тип снова карактеристични. ${ }^{5}$ Сумирајући разматрања везана за однос индивидуалног и традиције као „општег кода” у причама о сновима, Ј. Сафронов примећује да оне опстају на граници неодређености (ентропије) сновиђења и уређености традиције (Сафронов 2004: 223-224).

Фолклорност прича о сновима разматрана је и на нивоу структуре текста. М. Лурје (Лурье 2002) истиче да је тешко говорити о високој мери спонтаности у формирању прича о (пророчким) сновима, будући да се у њима релативно лако препознаје стабилан структурни образац. У идеалном облику, заснован је на следећим мотивима: опис животне ситуације која претходи сну, свакодневне околности које прате одлазак на спавање, прича о сновиђењу (често праћена описима психолошких стања пре и након сневања), размишљање о значењу сна или тумачење (које неретко даје ауторитет, старији из породице и сл.), испуњење предвиђеног, размишљање о сну и сневању уопште (Лурье 2002: 29-30) 6 . Овај теоретичар наново активира проблем динамике индивидуалног и колективног, те наглашава да се начини тумачења симбола у индивидуалним интерпретацијама неретко разликују од очекиваних (тј. оних које се реконструишу у етнолингвистичким интерпретацијама „народног сановника”; уп. и Kaivola-Bregenhøj 1993: 222). Управо су структурне особености, према Сафронову (Сафронов 2008а: 11-12), оно што приче о сновима чини специфичним у односу на друге фолклорне жанрове. Оне се темеље на две композиционе целине: садржај сна (Текст 1) и описивање са сном повезаних догађаја у равни (ауто)биографског искуства (Текст 2), а оваква структура уводи и, семантички и прагматички важну, опозицију „реалност”/,иреалност”. Текст 2 има обликотворну и функцију разграничења јер формира оквире наратива, маркира почетак и крај. Овако одређене структурне особености омогућиће аутору да приче о сновима доведе у везу са различитим жанровима фолклорне прозе: композициона целина Т1 одликама концептуализација простора и времена (у којима доминира неодређеност) блиска је бајци, а Т2 предању и причи из живота (тј. наративу личног искуства). Истовремено, поменуте одлике чине могућим да се о причама о сновима говори као о „контактном” жанру, будући да је у њиховој основи контакт два света (Сафронов 2004: 224).

\footnotetext{
${ }^{5}$ Највиши степен схематизованости одликује снове који су уклопљени у друге фолклорне жанрове (епску песму, хагиографску литературу и сл.) (Рабинович 2013: 50-52).

${ }^{6}$ Наративне равни прича о сновима које као стабилне издваја Кајвола-Брегенхој (KaivolaBregenhøj 1993: 218-220) нешто су другачијег типа, будући да је у овом сегменту разматрања ауторка ослоњена и на лингвистичка проучавања. Према њеним налазима, свака прича формира се кроз секвенцу епизода, а у формирању епизода могуће је препознати четири слоја наратива: експозиција (информације о ликовима, формирање сцене, успостављање просторно-временских оквира и сл.), компликација/заплет (увођење нечега што је неочекивано, важно, занимљиво), резолуција (повезивање линија радње), поука (коментари наратора везани за радњу, веродостојност и сл.).

${ }^{7}$ Сафронов наглашава неопходност увођења појма „иреалног“ уместо „нереалног“, будући да иреалне модалности не могу бити истините или лажне, већ могуће (Сафронов 2008в: 138).
} 
У разматрањима везаним за питање односа прича о сновима према жанровском систему „традиционалног” фолклора указано је и на блискост минималних текстова тумачења сна малим фолклорним жанровима чија је функција прогностичка (предвиђање времена, предвиђање будућности уопште и сл.; Небжеговска 1994: 72-73), док је, на основу структуре и логике тумачења, Н. Толстој довео у везу овај жанр и са загонетком (Толстой 1993). Коначно, приче о сновима блиске су и „визионарским жанровима” (у чије се оквире некада и у потпуности уклапају), различитим типовима нарација које тематизују искуство посете или виђења оног света. Осим на фолклорну, овакви наративи ослоњени су и на традицију апокрифне литературе и комплексно наслеђе визионарских текстова уопште (Толстой, Толстая 1995; Толстая 2003; Сафронов 2008б).

\section{Приче о сновима: о неким могућностима анализе теренске грађе}

Имајући у виду да класични етнографски и фолклористички извори, упркос обиљу података везаних за снове и сневање у традицијској култури, не пружају могућност за формирање екстензивнијег корпуса прича о сновима, проучавање оваквих нарација као фолклорног жанра подразумева укључивање грађе добијене кроз теренска истраживања. Стога ће у наставку овог рада бити укратко указано на потенцијалне правце и неке од могућности у анализи теренске грађе. Кроз досадашњи рад на терену аутор овог прилога формирао је релативно хетероген корпус наратива везаних за место снова у традицијској култури уопште, укључујући и различите типове прича о сновима (пророчке, снове о покојницима, култним местима и др.). Сегменти из два разговора, који ће у наставку бити представљени, показују, између осталог, и консеквенце различитости у примењеној методологији терена.

[разговор о подизању цркве на старом црквишту у селу Зупче]

И: А ел сањао можда неко да треба да направи? Се причало?

C: Па сањали, богами, овај, но неће да причу сан, сањали поједини па прилазали, па ишли те правили ти људи што су сањали, они отиду, купили даске, правили, помогли, све...

C: А не знате да ми испричате шта су сањали?

И: Не знам, богами, ја, слабо ти ја... Ја кад, кад сањам, кажу, треба да приложиш. Идеш у цркву, запалиш свеће. Ја то знам. То се пробудим, овај, каже, ти си дужан д-идеш да запалиш свећу у цркву, кад сањаш, неки сан тако, знаш. И ја послем, ако не могу, не могу, ако... Идем те запалим.

И: А шта кад сањаш?

C: Па не знам, кад сањаш нешто лоше, или... Каже, као божа кућа ми окренута око главе, то онда као докле та кућа око главе окрене, и то сањам, и ја, овај, то скочим, знаш, из кревета, и каже д-идеш у божу кућу да запалиш свеће. И ја купим [...] и запалим. [...] И приложим неки динар.

$[\ldots]$

И: А шта треба да се ради да се не сања лоше? Јел има оно да се? 
C: Не знам. Преврће неко јастук. Треба да преврнеш јастук. Треба да преврнеш јастук, ако си спавао на ову страну, да га преврнеш на ону страну. Па, каже, тако.

И: А ел има да кажеш нешто?

С: Па то неко, боже ме прости, уочи светога Јанићија, сад је свети Јанићије у недељу, пред Божић. [...] Кад идеш сад светога Јанићија и Богојављење, отидеш и узмеш у цркву светињу и то, и по три месте флашицу, и то да узмеш да окупаш и опереш косу и, каже, после неће... Да попијеш кад увати јутро, на пример, и нећеш после да сањаш никад.

И: А шта у три флашице?

С: У три. Од Богојављење, свети Јанићије и кад је неки црквени празник, на пример од Божић ово, узмеш светињу, знаш... [...] ти да по мало у флашицу, и ти саставиш то, од све три флашице, овај, од три светиње једну флашицу, и то да се окупаш кад бидне.

И: А кад треба да се окупаш?

C: Па, па саставиш све то.

И: А у кој дан треба да се купаш?

C: Па добро, кажу кад одлази се пијац овај, увече. Кад се одлази пијац овај, каже, увече. Тако ми рекла једна... Ја сам тела д-умрем, д-умрем, па сам ишла код једне у Пазар, нека жена, те ми рекла... То да окупаш, каже, кад одлази пијац, двапут недељно.

[саговорница говори о болестима, конвенционалном и магијском лечењу, а потом о смрти сестре]

И: А јеси сањала кад сестру?

C: Сестру... Нисам. Ни мајку ни сестру. Ја сам мајку издржавала, и гледала, и саранила. И није ми дошла на сан никако. Ни сестра, ни мајка. Ал ја углавном стално палим свеће, кад гоћ отиднем, ја палим, доле. Доле запалим, за сестру наменим, за мајку, за зета... оцу мојем, тако...

$[\ldots]$

И: Ал оће да дође тако људима на сан њихов ко је умро?

C: Па оће, ко си нешто грешан, на пример. Има неки, овде умрли. И сад он није, није гледан за живота. [...] И он, то баш његова жена ми причала, ту живе [...]. И кад су отишли на гробље, а он [умрли] дошо преко ноћи, нису ишли у цркву, каже: - Доћи ћу ја да ви узмем, каже, оно што је моје. Доћи ћу ја да ви узмем, каже, тамо има на совре шта ти душа жели, то ко је носио те делио, знаш, на пример, тамо има, каже, све што на тај свет, пуна совра, а ком није нико, каже, ко ја, нема ништа. - Овај нема ништа тамо. Каже: - Ја сам гледао тамо, каже, нема ништа. А они, каже, иму пуну совру, каже, не знам шта иму, каже, да потревим, ово што се носи..

(саговорница рођ. 1947. у селу Зупче, Зубин Поток; децембар 2004)

Демонстрирана стратегија диригованог дијалога показује се погодном за добијање прецизних информација о специфичним аспектима културе сневања (профилактичке радње везане за предупређивање лоших снова, тј. неутрализацију потенцијално негативног деловања сна који се перципира као лош - окретање јастука наопако, паљење свећа и прилагање новца цркви; уп. Гура 2001: 481). Кроз минималне коментаре саговорнице добијене су и информације које упућују на колективност поменутих пракси и знања. Уведена прича о сну открива и елементе локалне културе, неопходне за адекватно разумевање значења и аксиолошке димензије сна: из перспективе саговорнице сневање умрлог има негативан предзнак јер је примарно мотивисано кршењем табуа који функционишу у опхођењу према умирућем и у систему погребног обредно-обичајног комплекса (о различитим типовима снова о умрлима в. нпр. Сафронов 2006б; Hesz 2012). Додатно, јасно је назначен и пут трансмисије прича о сновима у усменој култури (То баш његова жена ми причала, пу живе...). 
У примеру који следи тема сна и сневања се отвара спонтано, асоцијативним везивањем за претходне теме разговора (демонолошки садржаји обликовани из перспективе личног искуства).

[разговор о вампирима; прича о самртниковој визији оног света]

Кажем, дал неква сила постоји, неко чудо, сестро мила, мора да има. Знаш, без ништа није. Исто, кад је умрла Драганова [мужевљева] баба, па беше оној инфлација, нема де да купиш пиво ни за лек, само у кафане. И она, знаш, узнемо ми и за сахрану смо стављали шприцер и сокови вишње, и ракију, друго, пиво, не имало. И по њу умре, не знам дал имало и дваес дана ил колико ли, син Војадин у Зајечар и један у Крагујевац, купили гајбу, да ли ови из Зајечар донел пиво. Дође пола године, нисам, сестро, ни мислела ни о томе размишљала, значи, нисам имала појма. И она дође ми на сан. И каже: - Е, Лело, што работите овој с мене, овој не убаво. - Кажем: - Чекај, бре, мамо, кво сад оћеш? Ем те чува, ем те преоблачи, ем све ти, па кво, реко, сад, па кво ти фали? - Е, па, рече, право да ти кажем, неј ово убаво. Све... - Она мираџика из Ресник, па њојно имање продавала там, овде купувала. - Све, рече, ћере, по моје одите, па пред сви има и пиво и сокови, а пред мен, ћере, нема. Саде пред мене нема ни пиво, ни сокови. - Па, реко, што ти то мен казујеш, ти си кажи на твоји. - Има синови. А она каже: - Ја казујем теб, а ти да кажеш на мојити синови. А ако они нече да купе, ти и Драган, мој муж, ти и Драган да ми купите и да ми донесете. - И ја кажем свекру, свекар каже: - Ма што ти мислиш за моу маћиу. [...] И ја кажем свекру, он каже: - Ти си мисли од твоји родитељи кад буде, ти од моу маћиу нема да мислиш, а он се одвојио од њи. [...] И, знаш, он каже: - Ја да се врне и башта, ја немам да од кво да купим. - Реко: - Драгане, иди, човече, у кафану у Црни вр дол у Бабушницу, па види, валда ће нађеш једну влашу кад дође време за пола годину, реко, приближава се баби, најди једну влашу пиво и једно шише сок купи стаклено, знаш, тад је било у стаклено шишети. И он отиде доле и за целу плату купио једну влашу пиво и једно од двеста грама сок, знаш, у стаклено шише. И послужимо гор, и никад ју више нисам сањала. Ето, па нек каже нећи да нешто нема. Постоје чуда. Исто кад сам била девојће, сањам ја, код Бога летим. Значи, идем код Бога. И лете, лете, лете, и стану. Куће ка у полукруг, значи, вата у полукруг, ал нема врата него само ко полукруг. Клупе у полукруг, столови у полукруг, опет клупе у полукруг, до зид. Све наседали стари људи. А Бог и Богородица, Бог на прво место, па онда она до њега седи. Ја слете и стану на прагат, знаш, и реко: - Леле, ја сам се забавила. - Он каже: - Ниси, ћере. Јао, рече, седни међу мене и међу Богородицу. - Ја седо. [...] Гледам, гледам, оно се угалашили људи. Ја чекам да се сви они исповеде. [...] - Боже, реко, ја док чекам да се ови свија исповеду, ја, реко, си има забавим, се вртам. Него, реко, могу ли ја да кажем кво имам, па да се врнем? - Кажи, каже, ћере! - Реко: - Ја работим у сви празници, само мајћа ми не дава и оп-, знаш на опасни верски празници. Греј ли је, неје, реко, ја тека. - А он ће рече: - Ћере, теби је дато у сви данови да работиш, а немој у четвртак. - А, реко, Боже, одма ће ме овам направе на замлатену. [смех] А он каже: - А што? - Реко: - Тека што код нас се празнује недеља, а ја празнијем четвртак, значи, ће ме гледу: - Оној замлатено, празнује четвртак. - E, рече, слушај, ћере... - Брада, ми се слика његова никад нема избрише. Као Павле што је био овија попа, сличан њему, ал није био толко мршав, знаш [...] као по округло лице. Каже: - Слушај, ћере, да ти кажем. Теби је дато у сви данови да работиш, и на опасни верски празници да работиш, теби Бог, теб се опрашта, нема ништа. Али само немој у четвртак. Ако работиш, ће да видиш да ће погрешиш. - Толико ли је, Боже? - Толико. - Дигнем се ја и појдем си, па се вртам, каже: - Запамти ли деда кво ти рече? У сви данови да работиш, ал немо у четвртак. - Ја испричам горе на мое, сам била девојка, они се смеју, знаш, била сам при Бога. [...] Нисам причала то уопште. Родим ћерку, прохода, дваес девети новембар, четвртак. Бубњарче, кубе, знаш оној бубњарче, срећа те било загасло. Играју се овај деца, комшичета, а ја гу пазим. [...] Кад оно, као да ми га оте неки из руке, паде на кубето, изгоре и чело, и нос, све се, сестро мила, кожа све се одлепи. Ја кад си писну: - Леле, реко, бабо! - на моу бабу: - Ја изгоре Драгану, реко, паде ми на кубе! - Како, бре, ћере! - Ја се сетим, четвртак, дваес девети новембар је био, али четвртак. Брже отрча за мелем, спасимо га. Терај, терај, и даље ме, знаш, то је сад као сьн. Кажу то нема ништа. Има, има чудо! Мушкото ми дрвен пиштољ правило, ја, уби слана на Јеремију, уби слана. И исто четвртак и петак било. Јај свекрва отидемо да пресађујемо пасуљ пошто га 
убила слана па по други пут, на Јеремију. И идемо да пресађујемо. Од работу, а муж легал да спија, ћерката писала домаћи у собу, а он онде у шупу правио си дрвен пиштољ. Па како удари, оно побегне му пиштољ, знаш. [...] И узне он и повреди се, за милиметар не исече вене и тетиве. [...] Овија [муж] се оклизну од дрво, без кору, четвртак поново, падне, строши кључну кост. Од таг сам ја рекла празнујем четвртак, на Велики четвртак постим, празнујем, као месим колач и све. Па нек прича кој шта оће, нек се смеје кој шта оће, мени се тој дешавало, значи трећи пут ме опоменуло код мужа.

(саговорница рођ. 1964. у селу Извор, Бабушница; јул 2018)

Уклапање садржаја снова у систем традиционалних представа лако се препознаје, а саговорница и експлицитно указује на њихово даље преношење у усменој комуникацији (кроз препричавање члановима породице). Први сан (умрли од живих захтева корекције у испуњавању обавеза везаних за погребни обредно-обичајни комплекс) сасвим је сличан оном из претходно анализираног примера. Други, сан о посети оном свету, у основи се уклапа у тип визионарских снова: сневач на необичан начин, у овом случају летењем, доспева на онај свет; стиче специфично знање и/или налог чије ће се поштовање/непоштовање рефлектовати на раван „,реалног” социјалног искуства (в. Толстая, Толстой 1995). „Веродостојност” сна потврђује се на две равни: наративној (епизоде које сведоче о последицама оглушења о добијени налог обликују трочлани градацијски низ) и метанаративној, у експлицитним коментарима који функционишу и као финалне формуле (Emo, па нек каже нећи да нешто нема. Постоје чуда; Па нек прича кој шта оће, нек се смеје кој шта оће, мени се тој дешавало, значи трећи пут ме опоменуло код мужа). У том контексту и читав наратив о сновима представља једну од низа потврда постојања и деловања оностраног, тј. његове улоге у формирању саговорничиног (аутобиографског) искуства.

У науци о фолклору у Србији проучавања снова у традицијској култури дала су лепе резултате у студијама Ж. Требјешанина, који се, ослоњен на методологију руске етнолингвистике, примарно фокусира на анализу симболичких представа (Требјешанин 2012а, 2012б). Антрополог Б. Јовановић (2017) сагледава снове као индивидуално неуро-психолошко искуство у ком се откривају и архетипски обрасци. Разматрајући различите аспекте сна и сневања (везу са митом, специфичности простора, времена, језика сна и сл.), посебну пажњу поклања анализи снова у оквирима политичких митологија, сновима везаним за култна места, те и ониричком коду у књижевном стваралаштву. Ипак, наративи о сновима нису били предмет фолклористичке анализе у најужем смислу. Разматрањем структуре, али и одлика концептуализације слике света у наративима о сновима отвориле би се додатне могућности за сагледавање места оваквих нарација у систему фолклорних жанрова. Осим што представљају тезаурус информација о специфичностима етнокултурних традиција, приче о сновима могу се посматрати и као део механизма конституисања социјалне реалности, са једне стране, односно, окренемо ли се плану индивидуалног искуственог - као елементи стратегија конституисања 
наративног идентитета. Коначно, теренска истраживања отварају и могућност за проучавање приповедних ситуација (dream telling), те и контекстуалних импликација у формирању наратива о сновима.

\section{ЛИТЕРАТУРА}

Веселова 2002: И. Веселова, Структура рассказов о снах, Сны и видения 6 народной культуре (ред. О. Б. Христофорова), Москва: РГГУ, 171-180.

Гура 2001: А. Гура, Сан, Словенска митологија (ур. С. М. Толстој и Љ. Раденковић), Београд: Zepter book world, 479-481.

Јовановић 2017: Б. Јовановић. Онирички код. Увод у антропологију снова. Београд: HERAedu.

Лурье 2002: М. Лурье, Вещие сны и их толкование, Сны и видения в народной культуре (ред. О. Б. Христофорова), Москва: РГГУ, 26-43.

Небжеговска 1994: С. Небжеговска, Сонник как жанр польского фольклора, Славяноведение 5, 67-74.

Панченко 2002: А. А. Панченко, Сон и сновидение в традиционных религиозных практиках, Сны и видения в народной культуре (ред. О. Б. Христофорова), Москва: РГГУ, 9-25.

Рабинович 2013: Е. И. Рабинович, Сны Пробуждённых: сон и сновидения 6 культуре, религии, политике Тибета, Екатеринбург.

Разумова 2001: И. А. Разумова, Потаенное знание современной русской семьи: Быт. Фольклор. История, Москва: Индрик.

Сафронов 2004: Е. В. Сафронов, „Вещее” сновидение и „сбывшееся” событие: механизмы соотнесения, Народная культура Сибири (ред. Т. Г. Леонова), Омск: ГПУ, 220-224.

Сафронов 2006а: Е. В. Сафронов, Рассказы о сновидениях: критерии фольклорности/нефольклорности, Культура \& общество, http://www.eculture.ru/Articles/2006/Safronov.pdf, приступљено 12. 11. 2018.

Сафронов 2006б: Е. В. Сафронов, „Иной мир” в рассказах о сновидениях и представлениях связанных с похоронно-поминальной обрядностью русских, Сньл и видения в славянской и еврейской культурной традиции (ред. О. В. Белова), Москва, 115-130.

Сафронов 2008а: Е. В. Сафронов, Рассказы об иномирных сновидениях в контексте русской несказочной прозы. Автореферат диссертации. Ульяновск: Ульяновский государственный педагогический университет имени И. Н. Ульянова.

Сафронов 2008б: Е. Сафронов, Переход в инобытие: рассказы о визионерском опыте, Живая старина 4, 23-25.

Сафронов 2008в: Е. Сафронов, О достоверности сна. Кирпичики. Фольклористика и культурная антропология сегодня (сост. А. С. Архипова, М. А. Гистер), Москва: РГГУ, 135-146. 
Толстая 2003: С. Толстая, Рассказы о посещении „того света” в их отношении к книжному жанру „видений”, Jews and Slavs 10, 43-54.

Толстой 1993: Н. Толстой, Славянские народные толкования снов и их мифологическая основа, Сон - семиотическое окно: сновидение и событие, сновидение и искусство, сновидение и текст (ред. Д. Ю. Молок), Москва: Государственный музей изобразительных искусств им. А. С. Пушкина, 80-93.

Толстая, Толстой 1995: С. Толстая, Н. Толстой, О жанре обмирания (посещения того света), у: Н. Толстой, Язык и народная культура. Очерки по славянской мифологии и этнолингвистике, Москва: Индрик, 458-460.

Требјешанин 2012а: Ж. Требјешанин, Симболика снова. Неке српско-руске фолклорне паралеле, Заједничко у словенском фолклору (ур. Љ. Раденковић), Београд: Балканолошки институт САНУ, 349-367.

Требјешанин 2012б: Ж. Требјешанин, Приче о сновима које наговештавају смрт и умирање, Етноантрополошки проблеми 3, 853-868.

Hesz 2012: A. Hesz, Hidden messages: Dream narratives about the dead as indirect communication, Vernacular Religion in Everyday Life: Expressions of Belief (eds. M. Bowman, Ü. Valk), New York, London: Routledge, 140-160.

Kaivola-Bregenhøj 1993: A. Kaivola-Bregenhøj, Dreams as Folklore, Fabula 34 (3-4), 211-224.

Shanon, Eiferman 1984: B. Shanon, R. Eiferman, Dream-reporting discourse, Text. Interdisciplinary Journal for the Study of Discourse 4/4, 369-380.

Smiljana Đorđević Belić

RESEARCHING DREAM STORIES: PROBLEMS AND PERSPECTIVES

(Summary)

This paper aims to briefly present the basic problem fields in folklore research on dreams, and to point out the possible directions and perspectives of future studies within the framework of the folkloristics in Serbia (genre issues, conceptualization of space and time, role in the constitution of social reality and individual narrative identity). 